\title{
Project-Based Learning in Online Postgraduate Education
}

\author{
Des Matejka \\ Australian Catholic University. Strathfield, Australia
}

\author{
d.matejka@mary.acu.edu.au
}

\begin{abstract}
The Faculty of Education at Australian Catholic University offers an online postgraduate course that focuses on the use of e-learning tools to facilitate changes in thinking, teaching and learning. It incorporates project-based learning techniques that require participants to learn how to apply selected ICT and e-learning tools to improve learning within their workplace. This has been based upon ongoing evaluations to determine ways in which experience with information and communications technology (ICT) and e-learning tools bring about a change of perspectives about their own teaching. Through identifying factors that inhibit, as well as promote their learning, the program focuses upon learning about ICT and e-learning tools to inform participants about their own teaching. This paper discusses how the implementation of an online postgraduate course has helped to facilitate a problem-based approach that provides a social construction for learning, by allowing the sharing of resources, discussion of approaches about implementation issues and the showcasing of final student projects.
\end{abstract}

Keywords: Project-based learning, online education, e-learning, learning, teaching, social construction, problem-based, postgraduate

\section{Introduction}

The growing trend for universities to offer postgraduate courses online (e-learning) is becoming increasingly attractive, as institutions seek to meet the needs of diverse student populations. (Maguire \& Matejka, 2000) discuss various economic, commercial and educational influences. (Felix, 2003) identifies institutional, academic and students factors driving this trend. The promise of increased enrollments has not materialized for many institutions, but the online mode attracts students with the flexibility it offers and new pathways for learning. Online learning offers the potential through the use of the Internet and the World Wide Web to improve opportunities for students' learning and to improve communication. The trend is aided by the widespread availability of low cost, low threshold e-learning tools such as email, web pages, real time chat, asynchronous discussion, streamed video and audio and other communication tools.

Since 1997, the School of Education (New South Wales) at Australian Catholic University, (ACU) has delivered a Post Graduate Certificate in Information and Communication Technology

Material published as part of this journal, either on-line or in print, is copyrighted by Informing Science. Permission to make digital or paper copy of part or all of these works for personal or classroom use is granted without fee provided that the copies are not made or distributed for profit or commercial advantage AND that copies 1) bear this notice in full and 2) give the full citation on the first page. It is permissible to abstract these works so long as credit is given. To copy in all other cases or to republish or to post on a server or to redistribute to lists requires specific permission from the publisher at Publisher@InformingScience.org
(PGCICT) to cohorts of geographically dispersed teachers and educators across Australia and internationally via the internet. The course was designed in consultation with educators to meet their continuing professional development needs of practicing teachers coming to grips with applying information and communications 
technology (ICT) tools to for administration and learning. These include developing an understanding of the roles of ICT in pedagogy, design, construction and evaluation of a learning web site, planning and implementing educational change incorporating ICT and online project-based learning. Since then, it has been reviewed and refined to meet the changing needs of employing authorities. The practitioners base the solution to their practical projects on theoretical underpinnings. The units are designed so that authentic problems from any educational workplace or from any educational system may be instantiated in them.

\section{Post graduate Online Model}

Offering the PGCICT entirely online without any face-to-face meetings has proven to be beneficial for all stakeholders. For the institution, and academics, it has provided viable cohorts of full fee paying students, where once these units failed to attract sufficient numbers to the local campus when offered in traditional face-to-face mode. For the students, mainly classroom teachers, it has offered flexibility by allowing these life-long learners to engage in accessing the learning materials and contributing to online discussions when and where they choose. This creates potential access to knowledge, a community of learners and professional qualifications as they undertake university study in the context of their workplace. For employing authorities they have appreciated ACU 's capacity to deliver quality training and professional development within the context of their e-learning needs. In traditional delivery modes, the teaching and learning model has been restricted to weekly attendance patterns, the e-learning model, utilising communication tools expands the opportunity for learning and interaction by bringing the learning resources and support structures into the workspace.

At ACU there has been considerable work undertaken, (Matejka \& Maguire, 2003) to develop a model for online learning using e-learning tools based upon, reference to the literature, experience of the expert presenters and evaluation of online teaching practice.

Examination of the literature reveals considerable support for the principle and practices implemented at ACU. Schneiderman's (1994) engagement theory encapsulates the features of the ACU model. Participants engage in project-based learning in collaboration with colleagues to seek practical solutions to authentic problems from within their own workplace. The learning paradigm uses a social constructivist model and a student centred approach as opposed to a transmission view of learning (Pea, 1996) that emphasises a teacher-centred whole-class approach to learning. The learning strategy is based on what Scott (1999) describes as a 'two-way view of learning' in which participants are invited to reflect on theory and relate this to practice wherever possible.

In undergraduate problem-based learning (PBL) courses a problem is usually defined for the learners who then acquire the knowledge to solve it in a series of stages. The ACU model is, however, based on adult learning (McConnell, 2002). The learners, who are already professional educators, collaborate to define a workplace problem and engage on a learning journey to solve it. They set their own learning outcomes within the broad parameters set by the assessment criteria. Hence, the projects within the PGCICT satisfy Reeves, Herrington and Oliver's (2002) authenticity requirements including real world relevance, being student-defined and collaborative, it has seamless integration with the formal assessment, providing students with the opportunity to reflect, it allows the development of solutions that have applicability across key learning area and the participants create valuable products in their own right.

Some of the key aspects of the presenters' experience revolve around student engagement. Of prime importance in the model, is the belief that feedback on assessment especially during the formative stages is most effective in improving students learning outcomes (Brown \& Knight, 
1994). An underlying goal is to promote the process of information use over its acquisition (Brown, 2000).

Ongoing evaluations of the e-learning program since its inception in 1998 have identified that there has been a change in learning perspective of the participants. As a result of studying online, ICT factors can be both promoters and inhibitors of learning performance, with ICT competence being a critical factor in e-learning. Another key finding relates to changes in learning perspectives (Matejka \& Maguire, 2003). The change in the participants' perspective on learning is a significant outcome of the on-line experience. The data has identified the following that learning becomes more outcomes focused and that the e-learning informs their teaching and that collaborative learning is a feature of their studies.

The participants report a close link between the outcomes of the project-based learning tasks they perform and the outcomes of their roles as educators and leaders. This is because they are engaged in authentic problem solving with direct applicability to the workplace.

The participants report levels of empowerment and increased capabilities to take on new roles as ICT leaders and mentors among their peers. They use their new knowledge to inform decisions about their own teaching and leadership roles. Participants report that the solutions to these work-based problems earn them broad respect and appreciation from their colleagues. As a result they are able to achieve higher levels of engagement with the corporate mission of their institution.

\section{Project-based Learning}

The use of project-based learning is used within the PGCICT to significantly enhance the development of understandings of ICT within an e-learning context and to develop experience with the pedagogy of online teaching and learning. PBL is used as a topic of study, a methodology for presenting e-learning and an opportunity to build greater student engagement in online teaching and learning.

Project-based learning (PBL) is a model for learning activity that shifts away from the instructional practices of short, isolated, content driven approaches, it instead emphasises learning activities that are long-term, interdisciplinary, student-centered, and integrated with real world issues and practices.

This approach allows teachers and learners to create tasks whose complexity and openness focus upon problems in the real world. One key benefit of PBL is that it lends itself to many disciplines, providing learners with the opportunity to have a voice in how and what they learn, while building intrinsic motivation towards problem-solving. The primary focus underpinning PBL teaching is the goal for 'Authentic Learning'

Teaching with PBL methodologies enables students and learners to work cooperatively with peers and mentors in a student-centered environment where learners are encouraged to explore various topics of interest. The level of student direction is designed to maximise student decision-making and initiative throughout the course of the project (Grant, 2002). Projects should include adequate structure and feedback to help students to make thoughtful decisions and revisions. By documenting students' decisions, revisions, and initiative, teachers (and students) will capture valuable material for assessing student work and growth.

"Project-based learning (PBL) isn't a new idea in education, but it's one that's finding new life. This renewed interest seems to come from the mounting evidence that we need to give our students more opportunities to exercise their higher-order thinking and problem-solving skills", (Share \& Rogers, 1997). 


\section{ICT and Project-based Learning}

ICT and Project-based learning can be used closely together. Through the use of word processors, slide show presentations, and web authoring packages students can present the information they have found. Research tools such as e-mail, electronic mailing lists, forums, and other online applications facilitate communication and collaboration with the world outside the classroom. Additionally, hypermedia (web) or multimedia (CD-ROM) enables the student to discover museums, libraries and information to assist in their work. ICT can also assist in the publishing of student's work, to be viewed by a real audience (Solomon, 2003). Setting up links between students across the world can form communities of learners.

Learning through hypermedia or multimedia and using authentic tasks requires learners to see the "relevance of the knowledge and skill to their lives, and the leverage it provides in problems they see as important" (Cunningham, 1991 cited by Carr \& Jitendra, 2000).

\section{Curriculum Engagement}

PBL not only assists in learning knowledge and solving problems, but also can help teachers and learners become more involved in the process of learning. A study that was conducted by (Carr \& Jitendra, 2000) has shown that the most obvious outcomes of PBL were that each student demonstrated expertise on a specific topic. This supplemented students' development of a sense of accomplishment and pride, along with increases in self-growth (e.g., confidence, self-esteem, and responsibility), learning engagement increased, and students acquired empathy for others. PBL allows each student to form an opinion and each student can feel positive about their contribution. The interest and motivation to engage in the project seemed to contribute to the students' success in this program.

Two examples of PBL as educational competitions, known as "webquests" are WebQuest (http://webquest.org/) and Thinkquest (http://www.thinkquest.org/). They both follow their own guidelines, which enable them to be unique forms of PBL.

Webquests take the learner on a journey that has no right or wrong answer. The nature of webquests is ill-structured domains, with lots of opportunity for students to construct knowledge and ideas from the material presented. The idea is for students to argue an opinion, not simply relate back someone else's thinking.

The webquest can generate enthusiasm and unleash enormous potential within both teacher and learner as they willingly venture into the unknown together (March, 2003). March also has developed the following rubric, which assesses the strengths and weaknesses of PBL. He sees the following as the highest qualities needed for a successful PBL:

1. Compels attention

2. Clear question and task which leads to sophisticated learning

3. Based on a common foundation of knowledge and resources

4. Provides multiple perspectives from which to view the topic

5. It is interactive, shows multiple perspectives and is current

6. Requires higher level thinking to construct meaning

7. Scaffolding is provided

8. Connected to the real world

9. Increases in sophistication as you move through the project (March, 2003) 
Projects challenge students to think by enabling them to do in-depth study at levels of complexity that often surprise teachers and parents. Teachers who are comfortable in letting students be free in their learning must guide PBL. The Project approach can be a vehicle for achievement of curriculum goals and for reaching standards of intellectual performance.

\section{Postgraduate Learning Using Project-Based Learning}

The challenge for the PGCICT is to bring together the demonstrated success of online education at ACU with the approaches advocated in PBL and demonstrated in practice in schools throughout the world.

The approach used was to engage the postgraduate learner in PBL development while the participant is also exploring and examining the rationale, underpinning and curriculum models used. A further requirement was to allow the approach to be sufficient broad to encompass non-school learning environments.

Participants in the PGCICT are familiar with action learning and action research models, so it was seen as useful to bring the students knowledge of these methodologies together with curriculum planning for PBL.

The scope of PBL needed to be broadened beyond the webquests undertaken in schools. Many of the postgraduate participants are schoolteachers, but a significant group are trainers, curriculum advisors and educational administrators. PBL had to accommodate the latter groups as well as schoolteachers.

\section{The PBL Task}

The task presented to the postgraduate learner was to develop a PBL task to be implemented and documented for a ten-week period. The participants were required to use the ICT skill and expertise to develop the PBL site, manage the e-learning activities and undertake file and data management.

Participants were required to examine the literature relating to PBL including examples and develop documentation that,

- developed a rationale for the use of PBL with reference to:

- Project-Based Learning in an Australian Context;

○ Learning theory that underpins Project-Based Learning;

- critiques features of successful uses of Project-Based Learning;

- provides details about assessment and evaluation procedures for PBL.

The task has proven to be an extremely rigorous one that extends planning and design of ICT projects and brings together pedagogy, learning theory and e-learning strategies.

\section{The PBL Postgraduate Learning Community}

The goals of this aspect of the PGCICT are to facilitate a problem-based approach to learning, provide a social construction for learning by allowing the sharing of resources, discussion of approaches about implementation issues and the showcasing of final student projects

PBL allowed for the achievement of these goals in a number of ways. Each participant PBL site is made available to all other postgraduate students throughout the course of study. Students frequently check each other's sites and had a readily accessible model for project development. As each teaching cycle commences, exemplar sites are made available to new students. The sharing 
of site development adds considerably a sense of developing PBL within a community of learners.

The use of discussion questions was used to within the learning community to support thinking about the PBL. The discussion topic relates to:

- What is Project-Based Learning?

- Rationale for Project-based Learning

- Essential Elements of a Good Project

- Planning For Project-based Learning

- Project Assessment Evaluation

The final showcasing of student projects demonstrated the effectiveness of implementing PBL within a postgraduate context. The assessment of the final projects was considered to be of less significance than the process of developing, facilitating and documenting PBL. Within the PGCICT we were interested in assessing how the perspectives of the postgraduate learners had changed and the impact that this would have on their own teaching. However, it was still necessary to make some evaluation of the final student project to ensure that quality projects were produced. The following questions and criteria were used as a reference for assessing the overall quality of the final projects.

- Is the project authentic?

- Does the project demonstrate academic rigor?

- Are the learning outcomes clearly identified?

- Does the nature of the project promote active exploration and the sense of a "learning community"?

- The technical quality of the project, including its reliability, ease-of-use, "look and feel" and navigation. The quality of the content of the project, including the accuracy and completeness of information, the expressiveness and clarity in communication of ideas, and the appropriateness of the attribution(s) for the work of others.

\section{Conclusion}

It has been demonstrated that Project-based Learning can be effectively implemented within a postgraduate learning environment. Participants report that the strategies and methodologies used in PBL have had a significant effect on their own teaching and their role as technology leaders. The approach lends itself to e-learning environments where participants can view and interact with the material produced by others. The PGCICT, which is focus upon social constructivism and participant engagement, allowed for more familiar sharing of ideas and discourse between participants than would otherwise be the case.

The use of PBL places high demands upon participants and development the time can be considerable. It is important to consider these issues when implementing this strategy and also recognise that postgraduate learners in the online context require considerable support as they develop PBL projects.

Finally the use of PBL represents a satisfactory mix of e-learning strategies, online pedagogy and socially constructed learning within a postgraduate context. 


\section{References}

Brown, J. S. (2000). Growing up digital: How the web changes work, education and the way people learn. Change, 32 (2), 10-20.

Brown, S., \& Knight, P. (1994). Assessing learners in higher education. London, UK: Kogan Page.

Carr, T., \& Jitendra, A. K., (2000). Using hypermedia and multimedia to promote project-based learning of at-risk high school students, Intervention in school and clinic (H.W. Wilson - EDUC). Sep 2000. Vol. 36, Issue 1, p. 40.

Dyrli, O, E. (1999). Finding staff development trees in the online forest. Curriculum Administrator, 35 (2), 18.

Felix, U. (2003). Teaching languages online: Deconstructing the myths. Australian Journal of Educational Technology, 19 (1), 118-138.

Grant, M. (2002). Getting a grip on project-based learning: Theory, cases and recommendations. Meridian: A Middle School Computer Technologies Journal, 5 (1).

McConnell, D. (2002). Action research and distributed problem-based learning in continuing professional education. Distance Education, 23 (1), 59-83.

Maguire, M. \& Matejka, D. (2000). On-line delivery: Making the rough road smooth. Paper presented at Flexible Learning for a Flexible Society. Proceedings of the ASET/HERDSA 2000 Joint International Conference 2000, Toowoomba, Qld. Retrieved from http://cleo.murdoch.edu.au/gen/aset/confs/asetherdsa2000/procs/contents.html

March, T. (2003). Working the Web Learning technology conference Brisbane 2003. Retrieved August 23, 2003, from http://www.ozline.com/

Matejka, D. \& Maguire, M. (2003). Using the workplace to develop authentic projects, new perspectives and directions in teacher learning. Paper presented at New Directions in Teachers' Working and Learning Environment. Proceedings of 11th Biennial Conference of the International Study Association on Teachers and Teaching, ISATT, 2003, Leiden, The Netherlands. Retrieved from http://www.ipn.unikiel.de/projekte/isatt/

Pea, R. (1996). Seeing what we build together: Distributed multimedia environments for transformative communications. In T Koschmann (Ed.), CSCL: Theory and practice of an emerging paradigm (pp. 171-186), Mahwah: Erlbaum.

Reeves, T. C., Herrington, J., \& Oliver, R. (2002). Authentic activities and online learning, In A. Goody, J. Herrington, \& M. Northcote (Eds.), Quality conversations: Research and development in Higher Education (25, pp. 562-567). Jamieson: HERDSA. Retrieved 21 April 2003 from http://www.ecu.edu.au/conferences/herdsa/papers/ref/pdf/Reeves.pdf.

Scheiderman, B. (1994). Education by engagement and construction: Can distance learning be better than face-to-face? Institute for Systems Research, University of Maryland. Retrieved 21 April 2003 from http://www.hitl.washington.edu/scivw/EVE/distance.html

Scott, G. (1999). Change matters: Making a difference in education and training. Sydney, NSW: Allen \& Unwin

Share, E., \& Rogers, L. (1997). Get real! Project-based learning. Mailbox Teacher, 25 (4), 61.

Solomon, G. (2003). Project-based learning: A primer. Technology \& Learning, 23 (6), 20.

\section{Biography}

Des Matejka is a lecturer in Information Technology and Education at Australian Catholic University. He has a background in teaching and using Information and Communications Technology (ICT) for learning. His current study and research is in the area of information technology, multimedia and instructional design, project-based learning and e-learning solutions. Des has taught 
programs using ICT with university participants in remote locations. His background and experience with ICT and teaching have led to a sound understanding of the use of ICT in distance education and the use of e-learning systems.

Research interests include, information and communications technologies, Web-based teaching and learning, using multimedia in education, instructional design, interface design for learning with information and communications technologies, implementing e-learning systems, using information technology for learning in Indigenous communities. 